\title{
Per Højholt
}

\section{Konfrontation med drømmen}

I dette bryst

skal alle skygger falde

og asken drages forgæves

med (mod?) ilden.

Vinden i træet er med

i fuglens elskovspagt -:

når næbbet brister $\mathrm{i}$ sang

slukkes alle lys.

Sværdet stiger drukkent

af forårets kumme

og blandt de uforløste

forledes et træ til løvspring.

Ilden tvinger fremmede kærtegn

i håndens arabesk

på de lukkede sten

ånder en mund uden læber.

På denne klippe

hvor jeg med mit blod

rejser vandets klippe

træder jeg ind i mit spejl.

Bag lyset og mørket

færdes skyggen med klare øjne

skjult bag stormen hviler vinden

ensom i sin årstid.

Over floden der har

mistet sine kærtegn

lukker kappen sig

om sine dolke.

I ørknens time den sene

blir jeg Èt med med min vandring

kildens klareste vand

breder jeg over mit ansigt.

Fuglens enkle bogstav

skal åbne min hånd

for en afvej som kan

rumme min længsel. 
Giv mig en sten på hånd og fod $\mathrm{O}$

og dine bønners spejl at bære $O$

giv mig et bæger

som kan tømme mine læber.

Giv mig lerets tørst

så jeg kan løse min ørken

(vær tavs min elskede

selv sneen mangler svar).

Dybt ved træets fod

regnens fanfare

på din hud og løvets purpur

mysteriets ånde:

Skyggen når lyset

uhjælpeligt står i midten

vandet $i$ hvis næb

fuglen kaster rede på rede.

Mørket som går forbi

min løftede hånd

sejlets bøn til båden om at

synke dybere end havet.

Blot blod der falder

som regn over intet $i$

drømmen der bøjer sit hoved

mere lukket end mindet.

Første gang trykt $i$ Erik Lindegrens tidsskrift, Prisma, nr. 2. 1950 (ikke siden optrykt, ikke navnt $i$ bibliografien $i$ Natur retur) 